\title{
The understanding of art students toward characteristic of Negeri Sembilan Minangkabau Traditional House
}

\author{
Nurul Shima Taharuddin ${ }^{1 a}$, Nurul Fadzila Zahari² and Asmalia Che Ahmad ${ }^{3}$ \\ ${ }^{1}$ Faculty of Art \& Design, Universiti Teknologi MARA, Cawangan Perak, 32610 Seri Iskandar, Perak. \\ ${ }^{2,3}$ Faculty of Architecture, Planning \& Surveying, Universiti Teknologi MARA, Cawangan Perak, 32610 Seri Iskandar, Perak.
}

\begin{abstract}
In Negeri Sembilan, they are still practicing Minangkabau culture and custom. Element of uniqueness in Negeri. Sembilan has been shown on its architectural where the houses have dramatic curved roof structures with multitier. The art and architecture features a unique regional style. This house fills with cultural values, customs and reflects the people's understanding about designing art and architecture that is in harmony with nature. The house serves as a residence, a hall for family meetings, and for ceremonial activities. This research, studies the understanding of art students towards the characteristic that are found in the Negeri Sembilan Minangkabau Traditional House (NSMTH) in Negeri Sembilan, Malaysia. The objectives are to identify the element of characteristic that shows the identity of Negeri Sembilan Minangkabau Traditional House and to determine the level of understanding on characteristic of a Minangkabau house by art students. Scope of this research is on understanding of Faculty Art \& Design student that has syllabus on Malay art. The research methodology that been use in this research is quantitative where surveys are made among the art students
\end{abstract}

\section{Introduction}

Negeri Sembilan is famous of its rich traditional culture and art. The Minangkabau Ethnic is one of the famous still practicing ethnic reside in Negeri Sembilan. Historically, going abroad was a part of requirement being Minangkabau men. All these men were expected to bring back fortunes and prosperity to their land. However, most of them migrate to other regions due to socio-economic reasons [1]. Its culture and art can be seen through the architectural style of their traditional house. The uniqueness of its upwards curved roof horn like shows the identity of Minangkabau ethnic and their history. It was told that there was a competition between village people and Jawa ethnic whom to said to conquer a land. It's a dual buffalo competition and when the winners win, they mimic the buffalo's horn in their roof style [2].

aCorresponding author: nuru1026@perak.uitm.edu.my

There are a few phases of transition by Minangkabau ethnic [3]. The transition happened in 7th century, which is from West Sumatera to Palembang and to Siak. First phase of transition happened inside Indonesia itself. Second transition happened from Palembang to Singapore in $11^{\text {th }}$ century to $12^{\text {th }}$ century which known as first generation transition. The last phase happened from Singapore to Negeri Sembilan in $12^{\text {th }}$ century to $15^{\text {th }}$ century known as second generation transition and it last until today [3]. 


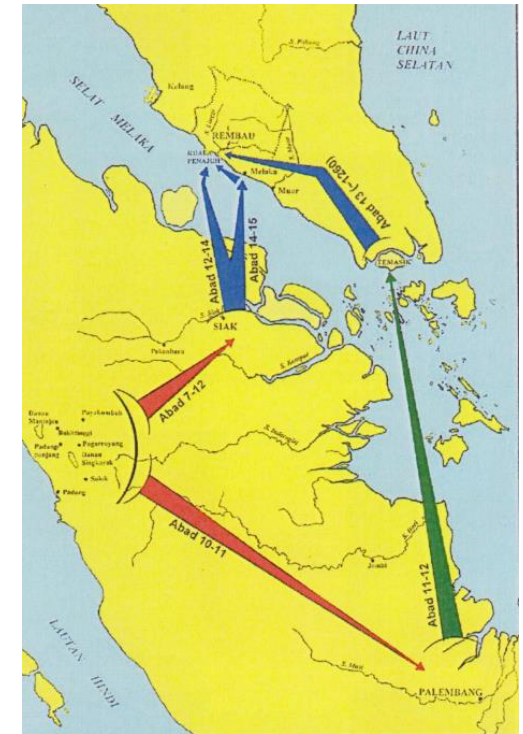

Figure 1: Transition movement pattern to Negeri Sembilan in early age [3].

The architectural style of Negeri Sembilan Minangkabau Traditional House (NSMTH) has a unique character compare to other traditional house. Negeri Sembilan Minangkabau traditional house are divided into a few elements. The first element is the curved roof, which becomes the identity of the traditional Negeri Sembilan house [4]. The curved shape of a roof at Minangkabau house, resemblance a shape of a boat [4]. It is due to the mix marriage of the "Biduanda Jawa" ethnic with Minangkabau ethnic [4] [5]. However there is also Minangkabau ethnic whom did not do mix marriage in order to maintain their original culture and custom [5]. It shows through the curved roof which resemblance the buffalo's horn. The research suggested the uses of two different names, which are The Negeri Sembilan Malay Traditional House on The Negeri Sembilan Minangkabau Traditional House, should be used (refer to figure 2).
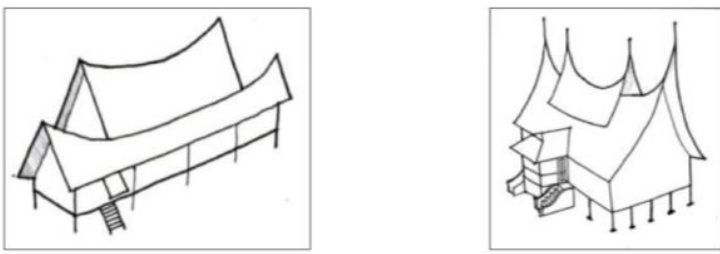

Figure 2 : (a)Sketch of typical Negeri Sembilan traditional house. (b)Sketch of Minagkabau traditional house in West Sumatera [5].

\section{Problem statements}

However, the uniqueness of traditional Minangkabau house has been forgotten and faded by influence of modern architectural style and living [1]. The interest amongst residence in Negeri Sembilan towards the architectural style of Minangkabau become less [1]. Due to less craftsmen interested in doing the Minangkabau Traditional house, the solution is to expose the knowledge about this unique characteristic to youngsters that will lead to sustainability of this Traditional house. As a result a survey on youngsters between 18 to 25 years old has been made to analyze the level of understanding among them towards the characters found in Minangkabau traditional house. Base on this result a solution will be made in order to solve the problem of lack of understanding about Minangkabau Traditional house among teenager.

\section{Aim and Objectives}

This research aims to explore the understanding of Art and Design student towards Negeri Sembilan Minangkabau Traditional House (NSMTH).

a) To determine the original characters of Negeri Sembilan Minangkabau Traditional House (NSMTH).

b) To investigate the level of understanding of Art and Design Students towards Negeri Sembilan Minangkabau Traditional House (NSMTH).

\section{Scope of Research}

The research scope was focus on Negeri Sembilan Minangkabau Traditional House (NSMTH). A survey towards 3rd Semester students was conducted among Higher Learning Education Institute students. These students consist of Diploma in Art and design students with five different courses; the courses are Fine Art, Fashion Design, Photography \& Digital Imaging, Graphic Design \& Digital Media, and Ceramic. Levels of understanding are determined based on the characteristics of Negeri Sembilan Minangkabau Traditional House (NSMTH).

\section{Literature Review}

Generally, Malay ancestors had built their house harmoniously to the occupants [7]. Most of Malay traditional house has similarity of its elements and characters such as most of traditional house must be built with column [4]. 
There are a few factors that influenced construction of a traditional house. Local climate, with a high temperature and rainfall pattern in certain area makes the air moist which will determine the character and design of the traditional house [4]. The Malay Archipelago is famous with richness of its forest and good timber and it is beneficial to the people in constructing their house [4].

All traditional houses have aesthetic value in its construction. Every space has its meaning, usage and philosophy [4]. According to the principle of space in a traditional house are divided into three parts which are front house, middle house and back.

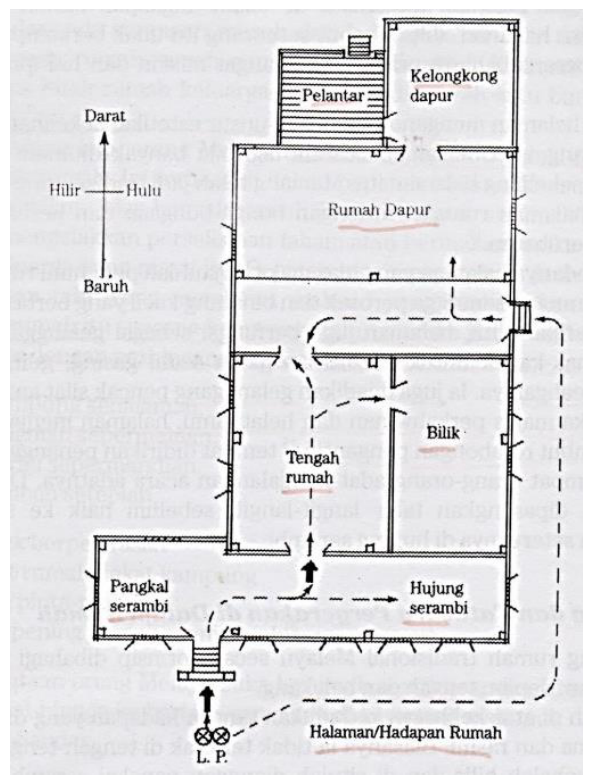

Figure 3 :Sketch of space in a traditional House [4].

There are a few characters at Negeri Sembilan Minangkabau Tradisional House, the upwards curved roof which resemblance shape of a boat (A. bumbung melentik) [4], A.1. papan gendeng a beautiful carved timber and A.2 gabled ( Tebar Layar). a triangle wood carving ornamentation with a hollow concepts which function as ventilation and lighting. The two layers roof was constructed on the middle space and extension space in front of the house on top of serambi [5]. The uniqueness of Negeri Sembilan house also shown on its multi-tiered roof structure ( B. Bumbung Berlapis) [8] and have a $\mathrm{C}$. long house and a beautiful N. courtyard. Interior space that been design in Negeri Sembilan Minangkabau Tradisional House divided into a few spaces with variety functions such as space for family gathering, entertain visitors, kitchens and private space [8]. Mother house or E. rumah ibu was divided into E.2 rooms, E.1 kelek anak, D. serambi rumah, F. peran or attic (loteng). F. Attic is a space to store things or used as a bedroom [4]. Besides space provided for family's activities, there are also space to entertain neighbour who come to the house, important person who came for discussion will be at the serambi. Most of traditional house were built with serambi [4]. Serambi were divided into three which are D.1 pangkal ( the beginning) serambi, D.2 middle serambi and D.3 end serambi. Other than that, serambi also can be used as a place to sleep by the son [4]. However, the begining of serambi is used to entertain the Adat people, while end serambi is for pious people and head of village [9].

The G. kitchen was divided into a few spaces which called asG.1 kelongkang dapur where it is used to cook and be a rear platform. The other space is called G.2 Pelantar belakang, this space is used to collect water from raining and save it in a tempayan [4].

Column is the main element constructed in a traditional house. The floor will be constructed higher than the ground to avoid wild animal and poisonous animal to enter the house [10]. In order to construct any traditional houses, I. column (tiang) is one of vital element. For a Negeri Sembilan Traditional house, column or tiang divided into four types which are I.1 tiang guntung which is a short column installed at the end of the edge of joist, I.2 tiang empat segi a column which built for external wall of a house, I.3 tiang pecah lapan a column used for kembi of pemidang wall system and lastly I.4 tiang seri which is a middle column located at the center of the mother house [4]. L. floor was divided into two which are L.1 normal floor and L.2 attic floor (lantai loteng). A floor was considered as a sacred and clean element meanwhile, floor for attic used to separate house area and the attic. Another common space in a Negeri Sembilan Traditional house is kolong which is located under the house. H. Kolong ( vault) is used as storage. J. Tunjak langit or King Post function to hold the roof trusses from collapse [11]. Negeri Sembilan Minangkabau Traditional House is famous with is construction technique not using single nails to connect its jointing or called as mortise technique or K. tanggam [4]. Usually NSMTH has M wood carving ornamentation on door, window and ladder. 


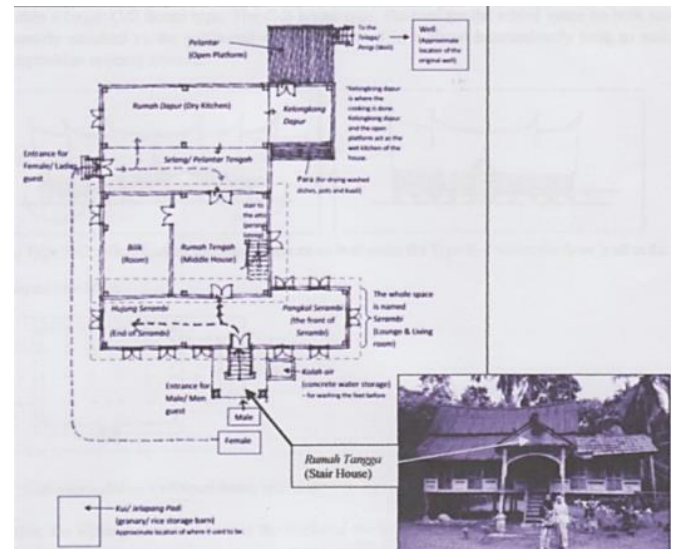

Figure 4 : A typical layout of Negeri Sembilan traditional house layput (Taipot mother of Moyang Ijah's house in Kg. Penajeh based on the $4^{\text {th }}, 5^{\text {th }}$ and $7^{\text {th }}$ generation description) with image of Esah (Uwan Itam) the owner which is the $4^{\text {th }}$ generation of Taipot [5]

\section{Research Methodology}

This research was conducted using quantitative survey method. A total of 122 students from five courses in Faculty or Art and Design were selected to be respondents in this survey. Art and design student has a syllabus on architectural Malays house, where the scope of the study is based on the characteristic or Malays house in Malaysia. Objective of this syllabus is to enhance the knowledge towards Malays traditional house so that in future this students will use the knowledge to produce an artwork that has Malays architecture identity in a way to promote Malays traditions and culture. Fine Art, Fashion Design, Photography \& Digital Imaging, Graphic Design \& Digital Media, and Ceramic Level of understanding among the students toward characteristics and unique elements of Negeri Sembilan Minangkabau traditional house is measured. In order to determine the level of understanding of Art student on characteristic of Minangkabau house, structure of question is based from book written by Idris Yaakob, Rumah Tradisi Negeri Sembilan. All question is based on the characteristic that been identified by Idris Yusof and was written in his book. There are twenty nine (29) characters of Negeri Sembilan Minangkabau traditional house has been distributed to all respondents. Out of 122 total respondents, only 113respondents answered the questionnaires. Input from this questionnaires were analyzed using Microsoft Excel 2010 Software and shown in various charts and bars. Table of frequencies is to show the data that has been collected and chart is to show the differences between departments. Each classes has difference background and difference interest.

\section{Findings}

Table 1: Frequencies Of Student according To Courses base on type of respondents residential.

\begin{tabular}{|c|c|c|c|c|c|c|c|}
\hline \multirow[t]{2}{*}{$\begin{array}{l}\mathrm{N} \\
\mathrm{o}\end{array}$} & $\begin{array}{l}\text { Type } \\
\text { Of }\end{array}$ & \multicolumn{5}{|c|}{$\begin{array}{l}\text { Frequencies Of Student According } \\
\text { To Courses }\end{array}$} & \multirow{2}{*}{$\begin{array}{l}\mathrm{T} \\
\mathrm{o} \\
\mathrm{t} \\
\mathrm{a} \\
1\end{array}$} \\
\hline & & $\begin{array}{l}\text { Fin } \\
\mathrm{e} \\
\text { Art }\end{array}$ & $\begin{array}{l}\text { Fas } \\
\text { hio } \\
\mathrm{n} \\
\text { Des } \\
\text { ign }\end{array}$ & $\begin{array}{l}\text { Photo } \\
\text { graph } \\
\text { y \& } \\
\text { Digit } \\
\text { al } \\
\text { Imagi } \\
\text { ng }\end{array}$ & $\begin{array}{l}\text { Graph } \\
\text { ic } \\
\text { Desig } \\
\text { n \& } \\
\text { Digita } \\
\text { l } \\
\text { Medi } \\
\text { a }\end{array}$ & $\begin{array}{l}\text { Cer } \\
\text { ami } \\
\text { c }\end{array}$ & \\
\hline $\begin{array}{l}1 \\
.\end{array}$ & $\begin{array}{l}\text { Trad } \\
\text { ition } \\
\text { al } \\
\text { Hou } \\
\text { se }\end{array}$ & 5 & 2 & - & 1 & 2 & $\begin{array}{l}1 \\
0\end{array}$ \\
\hline 2 & $\begin{array}{l}\text { Ren } \\
\text { ovat } \\
\text { ed } \\
\text { Trad } \\
\text { ition } \\
\text { al } \\
\text { Hou } \\
\text { se }\end{array}$ & 1 & 4 & 6 & 6 & 1 & $\begin{array}{l}1 \\
8\end{array}$ \\
\hline 3 & $\begin{array}{l}\text { Bun } \\
\text { galo } \\
\text { W }\end{array}$ & - & 3 & 3 & 8 & 2 & $\begin{array}{l}1 \\
6\end{array}$ \\
\hline 4 & $\begin{array}{l}\text { Terr } \\
\text { ace } \\
\text { Hou } \\
\text { se }\end{array}$ & 8 & 14 & 9 & 8 & 1 & $\begin{array}{l}4 \\
0\end{array}$ \\
\hline 5 & $\begin{array}{l}\text { Semi } \\
\text { Deta } \\
\text { ch }\end{array}$ & 1 & 3 & - & 2 & - & 6 \\
\hline 6 & $\begin{array}{l}\text { High } \\
\text { rise } \\
\text { Flat }\end{array}$ & 1 & 3 & 1 & - & - & 5 \\
\hline 7 & $\begin{array}{l}\text { High } \\
\text { rise } \\
\text { Apar } \\
\text { tmen } \\
\text { t }\end{array}$ & - & 3 & 1 & 5 & - & 9 \\
\hline
\end{tabular}




\begin{tabular}{|l|l|l|l|l|l|l|l|}
\hline 8 & $\begin{array}{l}\text { High } \\
\text { rise } \\
\text { Con } \\
\text { domi } \\
\text { nium }\end{array}$ & - & 3 & - & 1 & - & 4 \\
\hline
\end{tabular}

Chart 1: Frequencies Of Student according To Courses base on type of respondents residential.

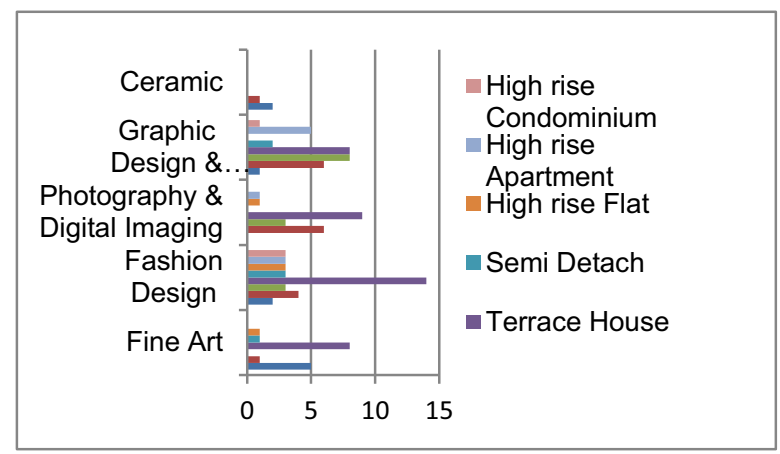

Frequencies of Student according to courses base on type of respondent's residential shows that majority of student living in a terrace house compare to other houses. Based on the results it shows that majority of the student didn't have much exposure to traditional house because they live in urban way of life. Usually the background of living influence the way student behave and think. This also implement to what characteristic of house they live in.

Data collection from survey among Fine Art students

Table 2: Mean on Level of Understanding towards of NSMTH

\begin{tabular}{|l|l|c|}
\hline No & $\begin{array}{l}\text { Characteristics Of } \\
\text { NSMTH }\end{array}$ & $\begin{array}{l}\text { Level Of } \\
\text { Understanding } \\
\text { (Mean) }\end{array}$ \\
\hline A & $\begin{array}{l}\text { Bumbung melentik } \\
\text { upwards curved roof) }\end{array}$ & 2.5 \\
\hline A.1 & $\begin{array}{l}\text { Papan gendeng a } \\
\text { beautiful carved timber) }\end{array}$ & 2.8 \\
\hline A.2 & $\begin{array}{l}\text { Tebar Layar (Gabled) } \\
\text { B }\end{array}$ & $\begin{array}{l}\text { Bumbung Berlapis } \text { (Multi- } \\
\text { tiered roof structure) }\end{array}$ \\
\hline C & $\begin{array}{l}\text { Rumah yang panjang } \\
\text { (Long house) }\end{array}$ & 2.5 \\
\hline D & $\begin{array}{l}\text { Serambi } \\
\text { D.1 }\end{array}$ & $\begin{array}{l}\text { Pangkal serambi ( the } \\
\text { beginning of serambi) }\end{array}$ \\
\hline D.2 & $\begin{array}{l}\text { Tengah serambi Middle of } \\
\text { serambi) }\end{array}$ \\
\hline
\end{tabular}

\begin{tabular}{|c|c|c|}
\hline D.3 & $\begin{array}{l}\text { Hujung serambi ( end of } \\
\text { serambi) }\end{array}$ & 2.2 \\
\hline $\mathrm{E}$ & rumah ibu (Mother house) & 2.5 \\
\hline E.1 & Kelek anak ( side room) & 2.4 \\
\hline E.2 & Bilik (rooms) & 2.9 \\
\hline $\mathrm{F}$ & Peran or loteng (attic) & 2.6 \\
\hline $\mathrm{G}$ & Dapur (Kitchen) & 3.2 \\
\hline G.1 & $\begin{array}{l}\text { Kelongkang dapur (where } \\
\text { it is used to cook and be a } \\
\text { rear platform) }\end{array}$ & 2.6 \\
\hline G.2 & $\begin{array}{l}\text { Pelantar belakang (space } \\
\text { is used to collect water } \\
\text { from raining and save it in } \\
\text { a tempayan) }\end{array}$ & 2.4 \\
\hline $\mathrm{H}$ & $\begin{array}{l}\text { Kolong (vault that use for } \\
\text { storage) }\end{array}$ & 2.6 \\
\hline I & Tiang (column) & 2.8 \\
\hline I.1 & $\begin{array}{l}\text { Tiang guntung (which is a } \\
\text { short column installed at } \\
\text { the end of the edge of joist) }\end{array}$ & 2.6 \\
\hline I. 2 & $\begin{array}{l}\text { Tiang empat segi (a } \\
\text { column which built for } \\
\text { external wall of a house) }\end{array}$ & 2.4 \\
\hline I. 3 & $\begin{array}{l}\text { Tiang pecah lapan (a } \\
\text { column used for kembi of } \\
\text { pemidang wall system) }\end{array}$ & 2.1 \\
\hline I.4 & $\begin{array}{l}\text { Tiang seri (which is a } \\
\text { middle column located at } \\
\text { the center of the mother } \\
\text { house) }\end{array}$ & 2.5 \\
\hline $\mathrm{J}$ & $\begin{array}{l}\text { Tunjak langit (King Post } \\
\text { function to hold the roof } \\
\text { trusses from collapse) }\end{array}$ & 2.8 \\
\hline $\mathrm{K}$ & $\begin{array}{l}\text { Tanggam (construction } \\
\text { technique not using single } \\
\text { nails to connect its jointing } \\
\text { or called as mortise } \\
\text { technique) }\end{array}$ & 2.5 \\
\hline $\mathrm{L}$ & $\begin{array}{l}\text { Lantai (floor will be } \\
\text { constructed higher than the } \\
\text { ground to avoid wild } \\
\text { animal and poisonous } \\
\text { animal to enter the house) }\end{array}$ & 2.8 \\
\hline L.1 & $\begin{array}{lll}\begin{array}{l}\text { Lantai } \\
\text { floor) }\end{array} & & \\
\end{array}$ & 2.8 \\
\hline L. 2 & Lantai loteng (attic floor) & 2.8 \\
\hline $\mathrm{M}$ & $\begin{array}{l}\text { Ukiran (wood carving } \\
\text { ornamentation on door, } \\
\text { window and ladder) }\end{array}$ & 2.9 \\
\hline $\mathrm{N}$ & $\begin{array}{ll}\begin{array}{l}\text { Halaman } \\
\text { (courtyard) }\end{array} & \text { Rumah } \\
\end{array}$ & 3 \\
\hline
\end{tabular}


Chart 2: Frequencies Level of Understanding towards of NSMTH

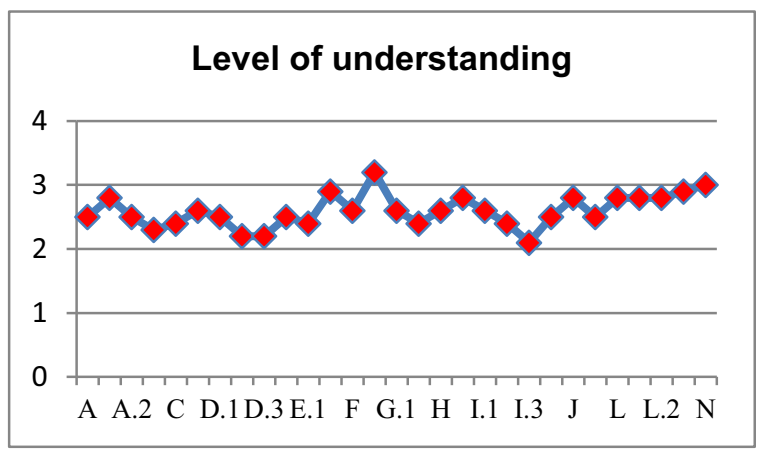

Highest average understanding of Fine Art students are 3.2 which is kitchen and the lowest is 2.1. which is Tiang Pecah Lapan. Kitchen is the most common knowledge in characteristic of a Negeri Sembilan Minangkabau Traditional House.While, the lowest knowledge is regarding Tiang Pecah Lapan. Most of modern house do not have Tiang Pecah Lapan. Total understanding of Fine Art students is between 2 and 3, which is fair and moderate. This result is the evidence of the level of understanding among teenager. Knowledge and awareness of using the knowledge is very importance in a way for this student to implement it in their work and use this knowledge in a future development.

Data collection from survey among Fashion Design students

Table 3: Mean on Level of Understanding towards of NSMTH

\begin{tabular}{|l|l|c|}
\hline No & Characteristics Of NSMTH & $\begin{array}{l}\text { Level Of } \\
\text { Understanding } \\
\text { (Mean) }\end{array}$ \\
\hline A & $\begin{array}{l}\text { Bumbung melentik } \\
\text { (upwards curved roof) }\end{array}$ & 3.2 \\
\hline A.1 & $\begin{array}{l}\text { Papan gendeng (a beautiful } \\
\text { carved timber) }\end{array}$ & 2.5 \\
\hline A.2 & Tebar Layar (Gabled) & 2.6 \\
\hline B & $\begin{array}{l}\text { Bumbung Berlapis (Multi- } \\
\text { tiered roof structure) }\end{array}$ & 3 \\
\hline C & $\begin{array}{l}\text { Rumah yang panjang (Long } \\
\text { house) }\end{array}$ & 3.1 \\
\hline D & $\begin{array}{l}\text { Serambi } \\
\text { D.1 }\end{array}$ & $\begin{array}{l}\text { Pangkal serambi ( the } \\
\text { beginning of serambi) }\end{array}$ \\
\hline
\end{tabular}

\begin{tabular}{|c|c|c|}
\hline D.2 & $\begin{array}{l}\text { Tengah serambi Middle of } \\
\text { serambi) }\end{array}$ & 2.2 \\
\hline D.3 & $\begin{array}{l}\text { Hujung serambi ( end of } \\
\text { serambi) }\end{array}$ & 2 \\
\hline $\mathrm{E}$ & rumah ibu (Mother house) & 2.3 \\
\hline E.1 & Kelek anak ( side room) & 2 \\
\hline E.2 & Bilik (rooms) & 3.5 \\
\hline $\mathrm{F}$ & Peran or loteng (attic) & 2.8 \\
\hline $\mathrm{G}$ & Dapur (Kitchen) & 3.5 \\
\hline G.1 & $\begin{array}{l}\text { Kelongkang dapur (where it } \\
\text { is used to cook and be a rear } \\
\text { platform) }\end{array}$ & 2.8 \\
\hline G.2 & $\begin{array}{l}\text { Pelantar belakang (space is } \\
\text { used to collect water from } \\
\text { raining and save it in a } \\
\text { tempayan) }\end{array}$ & 2.6 \\
\hline $\mathrm{H}$ & $\begin{array}{l}\text { Kolong (vault that use for } \\
\text { storage) }\end{array}$ & 2.6 \\
\hline I & Tiang (column) & 3.4 \\
\hline I.1 & $\begin{array}{l}\text { Tiang guntung (which is a } \\
\text { short column installed at the } \\
\text { end of the edge of joist) }\end{array}$ & 2.5 \\
\hline I. 2 & $\begin{array}{l}\text { Tiang empat segi (a column } \\
\text { which built for external wall } \\
\text { of a house) }\end{array}$ & 2.4 \\
\hline I. 3 & $\begin{array}{l}\text { Tiang pecah lapan (a } \\
\text { column used for kembi of } \\
\text { pemidang wall system) }\end{array}$ & 2.1 \\
\hline I.4 & $\begin{array}{l}\text { Tiang seri (which is a } \\
\text { middle column located at } \\
\text { the center of the mother } \\
\text { house) }\end{array}$ & 2.8 \\
\hline $\mathrm{J}$ & $\begin{array}{l}\text { Tunjak langit (King Post } \\
\text { function to hold the roof } \\
\text { trusses from collapse) }\end{array}$ & 2.4 \\
\hline $\mathrm{K}$ & $\begin{array}{l}\text { Tanggam (construction } \\
\text { technique not using single } \\
\text { nails to connect its jointing } \\
\text { or called as mortise } \\
\text { technique) }\end{array}$ & 2.2 \\
\hline $\mathrm{L}$ & $\begin{array}{l}\text { Lantai (floor will be } \\
\text { constructed higher than the } \\
\text { ground to avoid wild animal } \\
\text { and poisonous animal to } \\
\text { enter the house) }\end{array}$ & 3.3 \\
\hline L.1 & Lantai Biasa (normal floor) & 3.2 \\
\hline L.2 & Lantai loteng (attic floor) & 2.9 \\
\hline $\mathrm{M}$ & $\begin{array}{l}\text { Ukiran (wood carving } \\
\text { ornamentation on door, } \\
\text { window and ladder) }\end{array}$ & 3.4 \\
\hline $\mathrm{N}$ & $\begin{array}{l}\text { Halaman } \\
\text { (courtyard) }\end{array}$ & 3.6 \\
\hline
\end{tabular}


Chart 3: Frequencies Level of Understanding towards of NSMTH

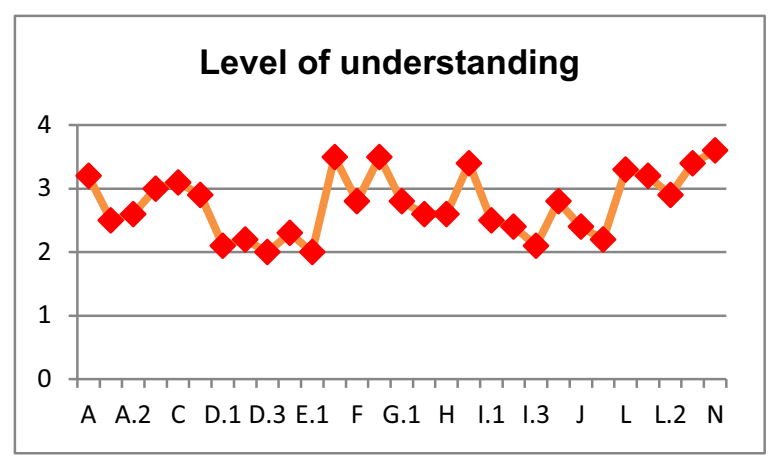

The highest scale from Fashion's students is 3.6 which is house yard (question N) and the lowest is end Serambi and Kelek Anak which is 2.0. Through the observation made by the author, the Fashion students have less knowledge on the traditional house characteristics. Fashion student have difference result majority of student can identify the characteristic of traditional house because, they have syllabus about traditional custom design and Minagkabau traditional house is one of the influence towards Minangkabau costume furthermore usually they have academic trip that sometimes the destination is Negeri Sembilan architecture for their subject matter. This means that fashion student have better exposure to traditional house compare to others.

\section{Data collection from survey among Photography \& Digital Imaging students}

Table 4: Mean on Level of Understanding towards of NSMTH

\begin{tabular}{|l|l|c|}
\hline No & Characteristics Of NSMTH & $\begin{array}{l}\text { Level Of } \\
\text { Understanding } \\
\text { (Mean) }\end{array}$ \\
\hline A & $\begin{array}{l}\text { Bumbung melentik (upwards } \\
\text { curved roof) }\end{array}$ & 1.6 \\
\hline A.1 & $\begin{array}{l}\text { Papan gendeng (a beautiful } \\
\text { carved timber) }\end{array}$ & 1.7 \\
\hline A.2 & Tebar Layar (Gabled) & 1.7 \\
\hline B & $\begin{array}{l}\text { Bumbung Berlapis (Multi- } \\
\text { tiered roof structure) }\end{array}$ & 2.0 \\
\hline C & $\begin{array}{l}\text { Rumah yang panjang (Long } \\
\text { house) }\end{array}$ & 2.3 \\
\hline D & Serambi & 2.1 \\
\hline D.1 & $\begin{array}{l}\text { Pangkal serambi ( the } \\
\text { beginning of serambi) }\end{array}$ & 1.5 \\
\hline
\end{tabular}

\begin{tabular}{|c|c|c|}
\hline D.2 & $\begin{array}{l}\text { Tengah serambi Middle of } \\
\text { serambi) }\end{array}$ & 1.6 \\
\hline D.3 & $\begin{array}{l}\text { Hujung serambi ( end of } \\
\text { serambi) }\end{array}$ & 1.4 \\
\hline $\mathrm{E}$ & rumah ibu (Mother house) & 1.7 \\
\hline E.1 & Kelek anak ( side room) & 1.6 \\
\hline E.2 & Bilik (rooms) & 2.9 \\
\hline $\mathrm{F}$ & Peran or loteng (attic) & 2.2 \\
\hline $\mathrm{G}$ & Dapur (Kitchen) & 3.0 \\
\hline G.1 & $\begin{array}{l}\text { Kelongkang dapur (where it } \\
\text { is used to cook and be a rear } \\
\text { platform) }\end{array}$ & 1.8 \\
\hline G.2 & $\begin{array}{l}\text { Pelantar belakang (space is } \\
\text { used to collect water from } \\
\text { raining and save it in a } \\
\text { tempayan) }\end{array}$ & 1.4 \\
\hline $\mathrm{H}$ & $\begin{array}{l}\text { Kolong (vault that use for } \\
\text { storage) }\end{array}$ & 1.8 \\
\hline $\mathrm{I}$ & Tiang (column) & 2.6 \\
\hline I.1 & $\begin{array}{l}\text { Tiang guntung (which is a } \\
\text { short column installed at the } \\
\text { end of the edge of joist) }\end{array}$ & 1.8 \\
\hline I. 2 & $\begin{array}{l}\text { Tiang empat segi (a column } \\
\text { which built for external wall } \\
\text { of a house) }\end{array}$ & 1.5 \\
\hline I.3 & $\begin{array}{l}\text { Tiang pecah lapan (a } \\
\text { column used for kembi of } \\
\text { pemidang wall system) }\end{array}$ & 1.4 \\
\hline I.4 & $\begin{array}{l}\text { Tiang seri (which is a } \\
\text { middle column located at the } \\
\text { center of the mother house) }\end{array}$ & 1.9 \\
\hline $\mathrm{J}$ & $\begin{array}{l}\text { Tunjak langit (King Post } \\
\text { function to hold the roof } \\
\text { trusses from collapse) }\end{array}$ & 1.6 \\
\hline $\mathrm{K}$ & $\begin{array}{l}\text { Tanggam (construction } \\
\text { technique not using single } \\
\text { nails to connect its jointing } \\
\text { or called as mortise } \\
\text { technique) }\end{array}$ & 1.9 \\
\hline $\mathrm{L}$ & $\begin{array}{l}\text { Lantai (floor will be } \\
\text { constructed higher than the } \\
\text { ground to avoid wild animal } \\
\text { and poisonous animal to } \\
\text { enter the house) }\end{array}$ & 2.7 \\
\hline L.1 & Lantai Biasa (normal floor) & 2.7 \\
\hline L.2 & Lantai loteng (attic floor) & 2.1 \\
\hline $\mathrm{M}$ & $\begin{array}{l}\text { Ukiran (wood carving } \\
\text { ornamentation on door, } \\
\text { window and ladder) }\end{array}$ & 2.4 \\
\hline $\mathrm{N}$ & Halaman Rumah (courtyard) & 3.3 \\
\hline
\end{tabular}


Chart 4: Frequencies Level of Understanding towards of NSMTH

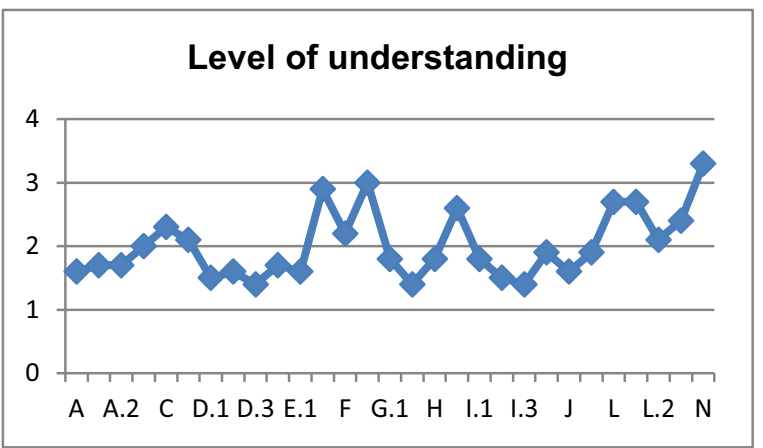

Based on the survey on Photography students, the highest scale is 3.3 (house yard) and the second highest scale 3 (kitchen) and the third highest is 2.9 (room). These three level of understanding are moderate. The lowest three scale are question D.3 (end serambi), question G.2 (rear platform) and question I.3 (tiang pecah lapan) which is 1.4. Photography student have the lowest knowledge towards Minagakabau traditional house because of lack of exposure. They usually have academic trip but their subject matter is more towards human and nature and they usually travel to east Malaysia which is Kelantan. Less exposure to Negeri Sembilan compare to Kelantan. This information is based on observation on photography approval academic trip. Student should be more creative in choosing the places for their subject matter exploration.

\section{Data collection from survey among Graphic Design \& Digital Media students}

Table 5: Mean on Level of Understanding towards of NSMTH

\begin{tabular}{|l|l|c|}
\hline No & Characteristics of NSMTH & $\begin{array}{l}\text { Level of } \\
\text { understanding } \\
\text { ( MEAN) }\end{array}$ \\
\hline A & $\begin{array}{l}\text { Bumbung melentik (upwards } \\
\text { curved roof) }\end{array}$ & 2.8 \\
\hline A.1 & $\begin{array}{l}\text { Papan gendeng (a beautiful } \\
\text { carved timber) }\end{array}$ & 2.4 \\
\hline A.2 & Tebar Layar (Gabled) & 2.7 \\
\hline B & $\begin{array}{l}\text { Bumbung Berlapis (Multi- } \\
\text { tiered roof structure) }\end{array}$ & 3.1 \\
\hline C & $\begin{array}{l}\text { Rumah yang panjang (Long } \\
\text { house) }\end{array}$ & 3 \\
\hline D & $\begin{array}{l}\text { Serambi the } \\
\text { D.1 }\end{array}$ & $\begin{array}{l}\text { Pangkal serambi ( thinning of serambi) } \\
\text { beginni }\end{array}$ \\
\hline
\end{tabular}

\begin{tabular}{|c|c|c|}
\hline D.2 & $\begin{array}{l}\text { Tengah serambi Middle of } \\
\text { serambi) }\end{array}$ & 2.5 \\
\hline D.3 & $\begin{array}{l}\text { Hujung serambi ( end of } \\
\text { serambi) }\end{array}$ & 2.3 \\
\hline$E$ & rumah ibu (Mother house) & 2.3 \\
\hline E.1 & Kelek anak ( side room) & 1.8 \\
\hline E.2 & Bilik (rooms) & 3.4 \\
\hline $\mathrm{F}$ & Peran or loteng (attic) & 3 \\
\hline $\mathrm{G}$ & Dapur (Kitchen) & 3.8 \\
\hline G.1 & $\begin{array}{l}\text { Kelongkang dapur (where it is } \\
\text { used to cook and be a rear } \\
\text { platform) }\end{array}$ & 2.9 \\
\hline G.2 & $\begin{array}{l}\text { Pelantar belakang (space is } \\
\text { used to collect water from } \\
\text { raining and save it in a } \\
\text { tempayan) }\end{array}$ & 2.6 \\
\hline $\mathrm{H}$ & $\begin{array}{l}\text { Kolong (vault that use for } \\
\text { storage) }\end{array}$ & 3.2 \\
\hline $\mathrm{I}$ & Tiang (column) & 3.6 \\
\hline I.1 & $\begin{array}{l}\text { Tiang guntung (which is a } \\
\text { short column installed at the } \\
\text { end of the edge of joist) }\end{array}$ & 2.4 \\
\hline I.2 & $\begin{array}{l}\text { Tiang empat segi (a column } \\
\text { which built for external wall of } \\
\text { a house) }\end{array}$ & 2.3 \\
\hline I.3 & $\begin{array}{l}\text { Tiang pecah lapan (a column } \\
\text { used for kembi of pemidang } \\
\text { wall system) }\end{array}$ & 2.1 \\
\hline I. 4 & $\begin{array}{l}\text { Tiang seri (which is a middle } \\
\text { column located at the center of } \\
\text { the mother house) }\end{array}$ & 2.6 \\
\hline $\mathrm{J}$ & $\begin{array}{l}\text { Tunjak langit (King Post } \\
\text { function to hold the roof } \\
\text { trusses from collapse) }\end{array}$ & 2.5 \\
\hline $\mathrm{K}$ & $\begin{array}{l}\text { Tanggam (construction } \\
\text { technique not using single nails } \\
\text { to connect its jointing or called } \\
\text { as mortise technique) }\end{array}$ & 2.5 \\
\hline $\mathrm{L}$ & $\begin{array}{l}\text { Lantai (floor will be } \\
\text { constructed higher than the } \\
\text { ground to avoid wild animal } \\
\text { and poisonous animal to enter } \\
\text { the house) }\end{array}$ & 3.8 \\
\hline L.1 & Lantai Biasa (normal floor) & 3.3 \\
\hline L.2 & Lantai loteng (attic floor) & 3 \\
\hline M & $\begin{array}{l}\text { Ukiran (wood carving } \\
\text { ornamentation on door, } \\
\text { window and ladder) }\end{array}$ & 3.5 \\
\hline $\mathrm{N}$ & Halaman Rumah (courtyard) & 4 \\
\hline
\end{tabular}


Chart 5: Frequencies Level of Understanding towards of NSMTH

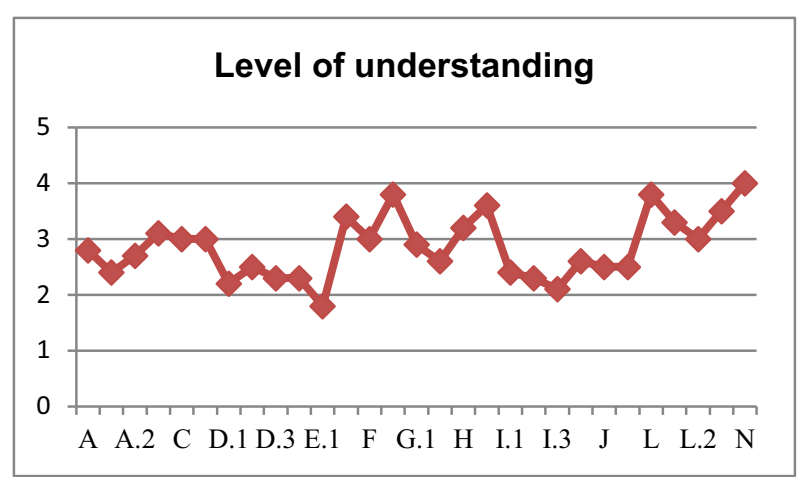

Result from questionnaire distributed among graphic students find that the lowest scale is 1.8 which is Kelek Anak while the highest scale is 4.0 which is yard. Level 4 of understanding indicate well and 1.8 is fair. There is large gap within variation characteristic of Negeri Sembilan Minangkabau Traditional House. Based on the graph above, there are five (5) characters in scale of 3.5 which are kitchen (question G), column (question I), floor (question L), ornamentation (question M) and house yard (question $\mathrm{N}$ ). These five characters are the main characters in most of traditional house in Malaysia.

Data collection from survey among Ceramics students

Table 6: Mean on Level of Understanding towards of NSMTH

\begin{tabular}{|c|c|c|}
\hline No & Characteristics of NSMTH & $\begin{array}{l}\text { Level of } \\
\text { understanding } \\
\text { ( Mean) }\end{array}$ \\
\hline A & $\begin{array}{l}\text { Bumbung melentik } \\
\text { (upwards curved roof) }\end{array}$ & 2.5 \\
\hline A.1 & $\begin{array}{l}\text { Papan gendeng (a beautiful } \\
\text { carved timber) }\end{array}$ & 2.2 \\
\hline A.2 & Tebar Layar (Gabled) & 2.2 \\
\hline B & $\begin{array}{l}\text { Bumbung Berlapis (Multi- } \\
\text { tiered roof structure) }\end{array}$ & 2.7 \\
\hline $\mathrm{C}$ & $\begin{array}{l}\text { Rumah yang panjang (Long } \\
\text { house) }\end{array}$ & 1.7 \\
\hline $\mathrm{D}$ & Serambi & 2.5 \\
\hline D.1 & $\begin{array}{l}\text { Pangkal serambi ( the } \\
\text { beginning of serambi) }\end{array}$ & 1.2 \\
\hline D. 2 & $\begin{array}{l}\text { Tengah serambi Middle of } \\
\text { serambi) }\end{array}$ & 1.3 \\
\hline D.3 & $\begin{array}{l}\text { Hujung serambi ( end of } \\
\text { serambi) }\end{array}$ & 1.2 \\
\hline $\mathrm{E}$ & rumah ibu (Mother house) & 1.3 \\
\hline
\end{tabular}

\begin{tabular}{|c|c|c|}
\hline E.1 & Kelek anak ( side room) & 1.2 \\
\hline E.2 & Bilik (rooms) & 3.2 \\
\hline $\mathrm{F}$ & Peran or loteng (attic) & 3.2 \\
\hline G & Dapur (Kitchen) & 2.5 \\
\hline G.1 & $\begin{array}{l}\text { Kelongkang dapur (where it } \\
\text { is used to cook and be a rear } \\
\text { platform) }\end{array}$ & 2.0 \\
\hline G.2 & $\begin{array}{l}\text { Pelantar belakang (space is } \\
\text { used to collect water from } \\
\text { raining and save it in a } \\
\text { tempayan) }\end{array}$ & 2.0 \\
\hline $\mathrm{H}$ & $\begin{array}{l}\text { Kolong (vault that use for } \\
\text { storage) }\end{array}$ & 2.2 \\
\hline $\mathrm{I}$ & Tiang (column) & 3.2 \\
\hline I.1 & $\begin{array}{l}\text { Tiang guntung (which is a } \\
\text { short column installed at the } \\
\text { end of the edge of joist) }\end{array}$ & 1.8 \\
\hline $\mathrm{I} .2$ & $\begin{array}{l}\text { Tiang empat segi (a column } \\
\text { which built for external wall } \\
\text { of a house) }\end{array}$ & 1.8 \\
\hline $\mathrm{I} .3$ & $\begin{array}{l}\text { Tiang pecah lapan (a } \\
\text { column used for kembi of } \\
\text { pemidang wall system) }\end{array}$ & 1.7 \\
\hline $\mathrm{I} .4$ & $\begin{array}{l}\text { Tiang seri (which is a } \\
\text { middle column located at the } \\
\text { center of the mother house) }\end{array}$ & 1.2 \\
\hline $\mathrm{J}$ & $\begin{array}{l}\text { Tunjak langit (King Post } \\
\text { function to hold the roof } \\
\text { trusses from collapse) }\end{array}$ & 1.7 \\
\hline $\mathrm{K}$ & $\begin{array}{l}\text { Tanggam (construction } \\
\text { technique not using single } \\
\text { nails to connect its jointing } \\
\text { or called as mortise } \\
\text { technique) }\end{array}$ & 2.2 \\
\hline $\mathrm{L}$ & $\begin{array}{l}\text { Lantai (floor will be } \\
\text { constructed higher than the } \\
\text { ground to avoid wild animal } \\
\text { and poisonous animal to } \\
\text { enter the house) }\end{array}$ & 4.0 \\
\hline L.1 & Lantai Biasa (normal floor) & 3.7 \\
\hline L. 2 & Lantai loteng (attic floor) & 3.2 \\
\hline $\mathrm{M}$ & $\begin{array}{l}\text { Ukiran (wood carving } \\
\text { ornamentation on door, } \\
\text { window and ladder) }\end{array}$ & 2.2 \\
\hline $\mathrm{N}$ & Halaman Rumah (courtyard) & 3.8 \\
\hline
\end{tabular}


Chart 6: Frequencies Level of Understanding towards of NSMTH

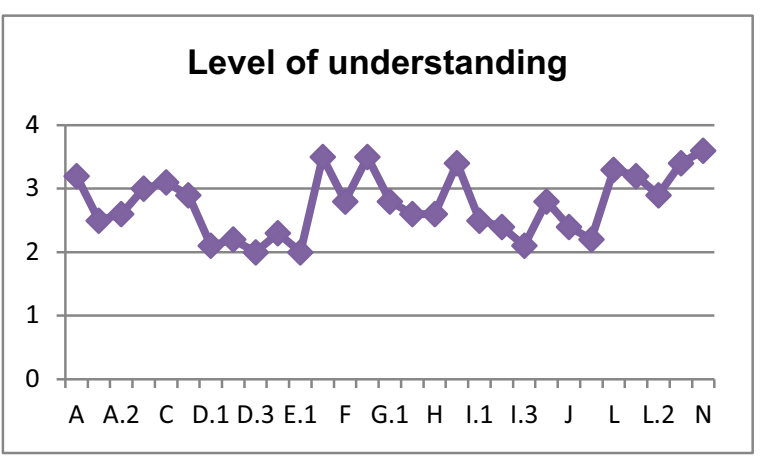

According to result from survey on ceramic's students, it shows that level of the understanding is good and high which is 4 (floor), second highest is house yard and the third highest is 3.7 (normal floor). There are five characteristics at poor level which are end serambi and kelek anak with 1.2 scale, middle serambi and mother house at scale of 1.3. Ceramic student have a better exposure towards house characteristic because they have to study a lot on structure. One of their syllabus is to study structure of building and usually the theme is traditional house. In a way to understand the house structure they have to read about the house and this give them extra knowledge.

Chart 7: Overall of Level of Understanding on NSMTH by Faculty of Art and Design students.

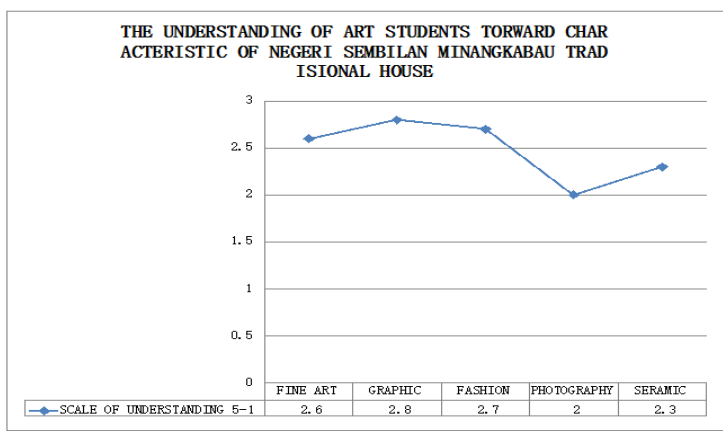

From the graph above, the level of understanding among students of different programs of faculty of art and design is moderate and fair. Fine Art, Graphic, and Fashion's students each with average 2.6, 2.8 and 2.7 is at moderate level. While another two programs which are photography and ceramic with level of 2.0 and 2.3 which is fair. Overall, the faculty of art and design majority lives in concrete modern house which is 40 respondents, bungalow 16 respondents, Semi Detached house 6 respondents, condominium 4 respondents , apartment 9 respondents and Flat 5 respondents. Only 10 of the respondents' lives in kampong traditional house and the rest lived in Renovated Traditional house. Due to the type of residential the respondents' lived cause the lack of knowledge and understanding about traditional house.

\section{Conclusion}

In conclusion, the students of faculty art and design have poor to good understanding on main elements and characters of NSMTH in Malaysia. The elements with a higher level of understanding are Floor, House Yard, Normal Floor, Kitchen, pillar and ornamentation. Detail characteristics and elements OF NSMTH such as pangkal serambi, end serambi, kelek anak, middle serambi, mother house, rear platform and tiang pecah lapan. Based on findings, the author suggest to raise the awareness and knowledge of youngsters nowadays to learn about Negeri Sembilan Minangkabau Traditional house. The exposure and experiential learning about this can be done through sketches, drawing and photography as their assignments. By this type of learning process they can make the students appreciate the uniqueness characteristic of NSMTH.

\section{References}

[1] Abdullah, F. Wongso, J. (2007), A Study of Minangkabau Architecture in Two Region: West Sumatra, Indonesia and Negeri Sembilan, Malaysia. The Second International Coferance of the Center for the Study of Architecture in the Arab Region. CSAAR. [2] Exploring Indonesia, (2007). Past and Present. Retrieved on April 27, 2007 at http://www.hawaii.edu/cseas/pubs/indonesia.indonesia $\underline{\text { html }}$

[3] Lembaga Muzium Negeri Sembilan, (2011). Sistem Sosial Adat Perpatih Di Luak Inas. Jalan Sungei Ujong, Negeri Sembilan. Lembaga Muzium Negeri Sembilan. ISBN 978-983-2877-13-4

[4] Y. Idrus, (1996). Rumah Traditional Negeri Sembilan: Satu Analysis Seni Bina Melayu. Shah Alam, Selangor: Penerbit Fajar BaktiSdn. Bhd. ISBN 967-65-3585-0

[5] M. Masri, (2012). The Misconceptions Of Negeri Sembilan Traditional Architecture. Procedia - Social and Behavioral Sciences 68 (2012) 363 - 382. Giza, Egypt.

[6] Abdullah, F. (2012). Losing Interest of Minangkabau Architecture. IIUM Research, Invention and Innovation Exhibition 2012.

[7] Hassan, I.S., Ismail, I. and Ismail, M.A (2013) The Islamic Concept of Minangkabau Architectural Heritage, Conference Paper. 
[8] Bahauddin, A., (2012). The Minangkabau House: Architectural and Cultural Elements. WIT Transactions on Ecology and The Environment, Vol 165. www.witpress.com, ISSN 1743-3541.

[9] Ibrahim, N. H., (2007). Rumah dan Peralatan Olek serta Permainan Tradisional Negeri Sembilan. Jalan Sungei Ujong, Negeri Sembilan. Lembaga Muzium
Negeri Sembilan. ISBN 978-9832877-02-8

[10] Nasir ,A. H.. (1985). Pengenalan Rumah Tradisional Melayu Semenanjung Malaysia. Cheras. Darulfikir.

[11] Shahminan, R. N. R.. (2007). Senibina Rumah Bumbung Panjang Negeri Sembilan. Adat Perpatih Esei Pilihan , 191-197. 